Reprod. Nutr. Dévelop., 1983, 23 (4), 783-792.

\title{
Effect of amylomaize starch on cholesterol and bile acid metabolisms in germfree (axenic) and conventional (holoxenic) rats
}

\author{
E. SACQUET, C. LEPRINCE, M. RIOTTOT
}

Laboratoire des Animaux sans Germes, C.N.R.S.

I.N.R.A., 78350 Jouy-en-Josas, France.

\begin{abstract}
Summary. Germfree and conventional rats were given a semi-synthetic diet containing either normal cornstarch or an amylomaize starch. The experimental groups thus formed were compared to assess the effects of these two types of starch and to determine if digestive tract microflora was involved in these effects.

The presence of amylomaize starch decreased body growth in germfree and conventional rats, increasing food intake in the former and decreasing it in the latter. In conventionals, amylomaize starch decreased the apparent digestibility of the ration only slightly, while in germfrees it diminished apparent digestibility considerably. The cecal weight of germfree animals was not modified by amylomaize starch but that of conventional rats was increased fourfold.

In both types of rat, amylomaize starch largely decreased the plasma concentration of cholesterol, largely increased the total amount of bile acids in the small intestine but slightly modified the fecal elimination of cholesterol and bile acids. It augmented the cholesterol concentration in the liver of germfrees and decreased it in conventionals while, on the contrary, it diminished the total amount of bile acids in the hind gut in the former and augmented it in the latter. This starch did not change bile acid deconjugation in conventional rats but considerably decreased other bacterial transformations of cholesterol and bile acids.

Digestive tract microflora was undoubtedly involved in the action of amylomaize starch on cecal weight, ration digestibility, food intake, hepatic cholesterol concentration, the amount of bile acid in the hind gut and obviously in the transformation of cholesterol and bile acids. It did not play a role in the other effects of this starch : the strong decrease in the concentration of plasma cholesterol was the direct effect of amylomaize starch on rat metabolism.
\end{abstract}

\section{Introduction.}

Many studies have been done on the effects of dietary components on cholesterol and bile acid metabolisms. Dietary fiber and lipid have been especially well investigated. Little work has been carried out on the effects of various starches or on the role of digestive microflora in the action of starches on these metabolisms. Kellogg (1971) reported the disappearance of some bacterial metabolites of bile acids in conventional rats fed a potato starch diet. Carroll et al. (1978) described the decrease of cholesterolemia and the increase of cholesterol trans- 
formation into bile acids in rats fed such a diet and the hypocholesterolemic effect this diet had in rabbits. Recently, we showed that the way in which the cornstarch diet was sterilized and the form in which it was given modified bile acid metabolism in rats (Sacquet et al., 1979; Riottot et al., 1980).

The present work compares the effects of two types of cornstarch on cholesterol and bile acid metabolisms in germfree and conventional rats. One of the starches was normal cornstarch, rich in amylopectin and poor in amylose; the other was an amylomaize starch particularly rich in amylose. The aim of this study was to assess the effect of these two types of starch and to determine if the microflora was involved in these effects.

\section{Material and methods.}

Animals and diets. - We used germfree (GF) and conventional (CV) inbred Fisher male rats from our colony. The GF rats were maintained in plastic isolators according to the technique of Trexler (1959). The CV rats were kept in our animal room.

The composition of the experimental diet was the following : starch $60 \mathrm{~g}$, casein $20 \mathrm{~g}$, cornoil $9 \mathrm{~g}$, cellulose $5 \mathrm{~g}$, mineral salts $4.5 \mathrm{~g}$, vitamins $\mathrm{S}$. A. The diet did not contain any cholesterol. The amylomaize starch, containing between 65 and $75 \%$ of amylose, was registered under the name of "Eurylon " (Roquette Frères, Lestrem, F62136). The diets were called N (normal starch) and $E$ (Eurylon), and the rats were divided into experimental groups GFN, CVN, GFE, CVE. The diet, sterilized by gamma irradiation at $40 \mathrm{KGray}$ in vacuumsealed polyethylene bags, was admixed with an equal weight of water to make a paste before it was given to the rats.

Cholesterol isotopic equilibrium. - This technique (Chevallier and Lutton, 1966) was used for technical reasons. When cholesterol isotopic equilibrium is obtained, the liver, blood cholesterol and different chemical species of bile acid have equal specific activity, making it easy to determine bile acid intestinal pools and fecal excretion. In this experiment, cholesterol isotopic equilibrium was obtained by feeding the animals from 2 months of age with the experimental diet containing $45000 \mathrm{dpm} / \mathrm{g}$ of $\left(4-{ }^{-14} \mathrm{C}\right.$ )-cholesterol (CEA, Saclay; specific activity: $40 \mathrm{mCi} / \mu \mathrm{mole}$ ). After 8 weeks the feces were collected for 2 weeks. The rats were then anesthetized and killed by puncture of the abdominal aorta; the blood, liver and intestines were collected and the cecum was weighed immediately. Hepatic cholesterol, intestinal pools and fecal excretion of bile acids were determined as described previously (Sacquet et al., 1975, 1977), i.e. briefly, the organs and feces were ground and extracted by boiling ethanol in a Kumagawa apparatus. The acid and neutral sterols were separated according to Grundy et al. (1965). To determine the specific activity of liver cholesterol, the mass was measured using Liebermann's technique and radioactivity was determined by liquid scintillation. The different chemical species of bile acid were separated by TLC of the methyl esters on silicagel $G$ with chloroform-acetone-methanol $(70 / 25 / 5)$ as the mobile phase. 
To determine plasma cholesterol, one $\mathrm{ml}$ of plasma was saponified and then extracted by petroleum ether. Radioactivity was counted in the scintillator and the mass was obtained by dividing counted radioactivity by the specific activity of liver cholesterol.

The mass of fecal cholesterol was determined by dividing unsaponifiable radioactivity by specific fecal cholesterol activity. To obtain this mass, the cholesterol was first separated by thin-layer chromatography. We had to carry out two chromatographies on extracts obtained from conventional rats. The first, on alumina gel containing $1 / 3$ of its weight in silver nitrate with a mobile phase of chloroform-petroleum ether-acetone $(60 / 30 / 6)$, separated the $5 \alpha$ and $5 \beta$-sterols. After chloroform elution of the cholesterol band, the eluate was chromatographed a second time on silica gel with an ethyl ether-heptane mixture (55/45), followed by chloroform elution. Only the second chromatography was used for GF rats. Cholesterol was then assayed by gas-liquid chromatography on a pyrex column $2 \mathrm{~m}$ long and containing $3 \%$ OV 17 and $3 \%$ OF 1 absorbed in equal parts on chromosorb WHMDS $80 / 100$ mesh (Applied Science Lab, Inc.) at $235^{\circ} \mathrm{C}$.

Statistical methods. - The results of each studied characteristic were expressed by the mean value and the SDM (SD of the mean). The four experimental groups were compared by two-factor analysis of variance (Snedecor and Cochran, 1957) and the interactions of the two factors (microflora and starch) were determined.

\section{Results.}

General characteristics of the rats. - The general characteristics of the rats are shown in table 1. At the end of the experiment, the body weight of GFN, GFE and CVN rats was similar, while that of CVE rats was lower. However, over the 2 months the animals were given the experimental diets, weight gain was less in those receiving diet $E$ than in those given diet $N$ and in GF than in CV rats. The dry matter digestibility ratio was much lower in GFE rats than in the other three groups. This low value was mostly due to the fact that GFE rats digested less amylomaize starch. Microscopic examination of these feces showed many undigested starch grains, while these grains were completely absent in CVE rats. GFE animals ingested more of the diets than GFN rats and, on the contrary, CVE rats ingested less than CVN rats.

The cecal weight of GF animals was not significantly altered by the presence of amylomaize starch, although its water content decreased. On the contrary, the cecal weight of CVE rats augmented considerably.

Hepatic and plasma cholesterol (table 2). - The concentration of plasma cholesterol decreased in the same way in GF and $\mathrm{CV}$ rats under the effect of diet $\mathrm{E}$. The concentration or total content of cholesterol in the liver per $100 \mathrm{~g}$ of body weight varied in an opposite way in germfrees and conventionals : it was 


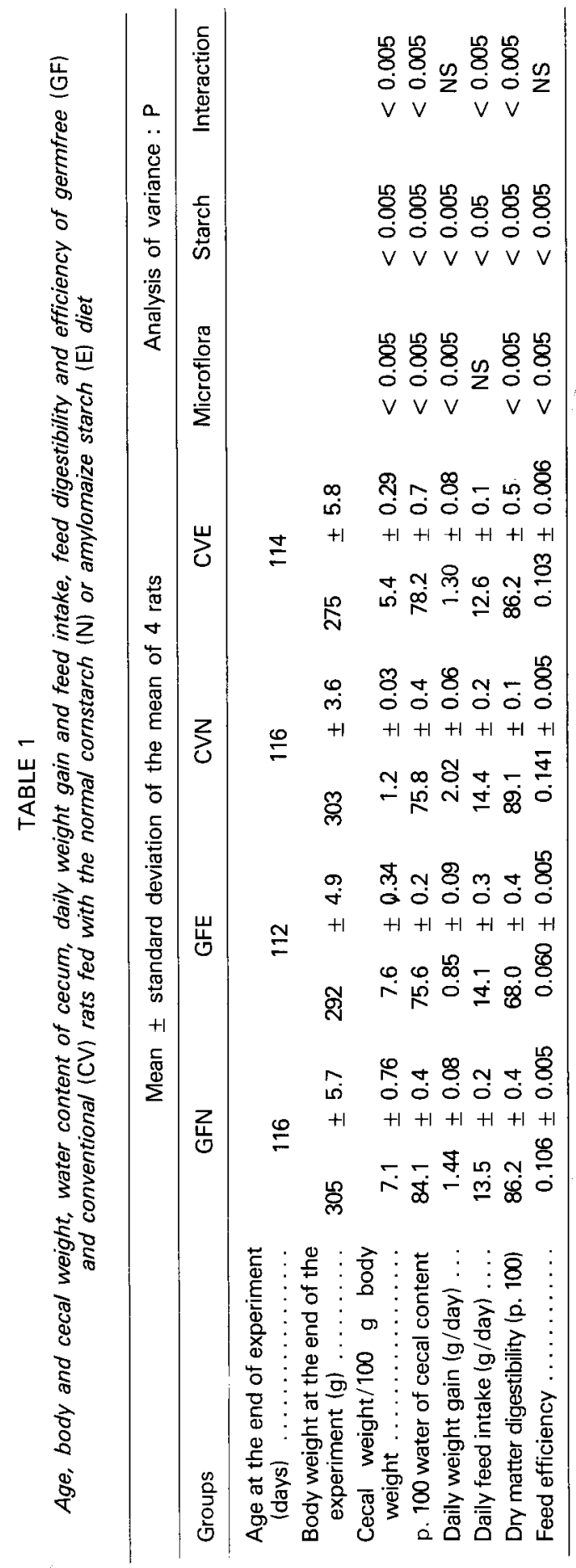


Starch, microflora and cholesterol metabolism
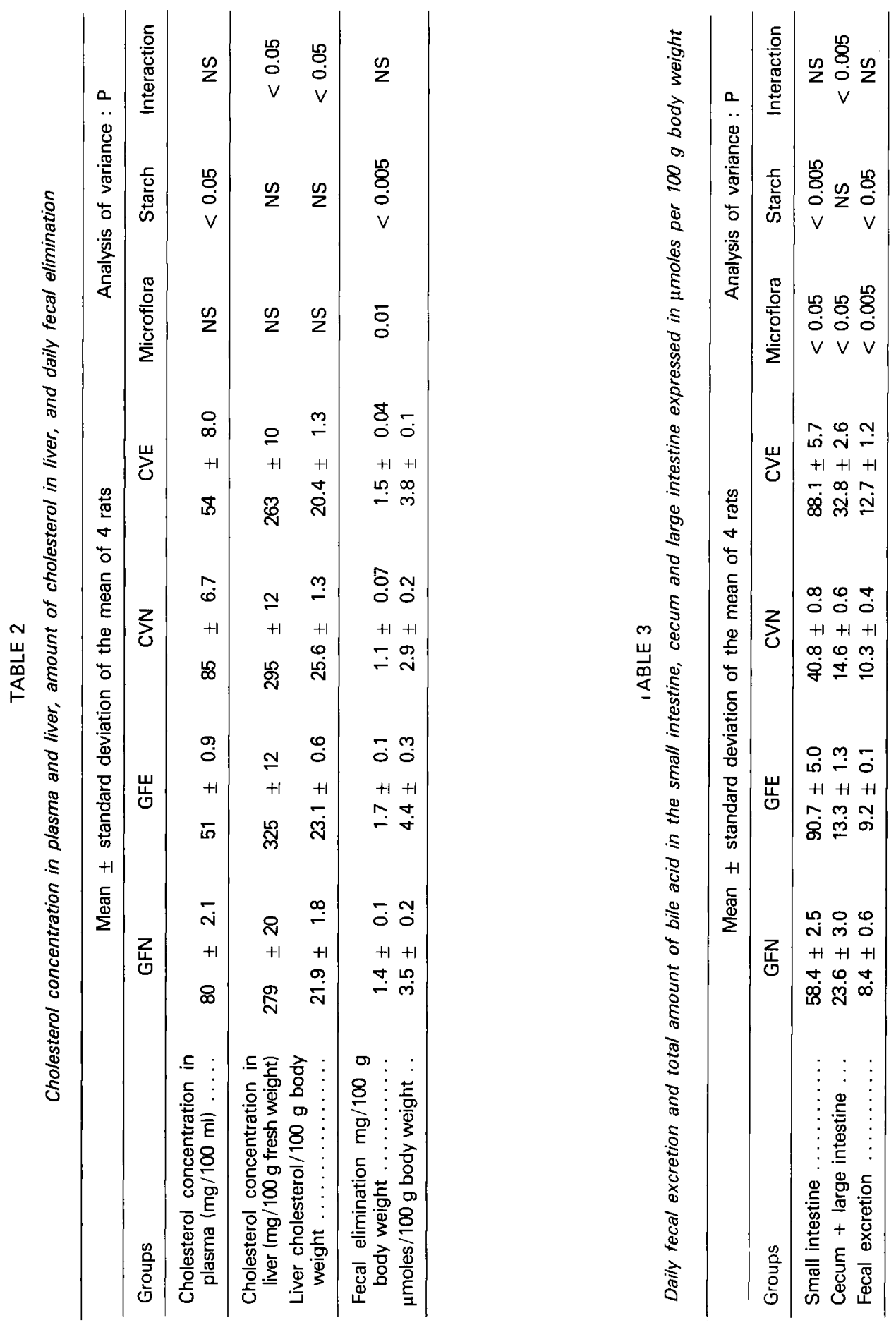
higher in GFE than in GFN rats and, on the contrary, was lower in CVE than in CVN rats.

Fecal elimination of cholesterol (table 2). - Fecal elimination of cholesterol was higher in GF than in $\mathrm{CV}$ animals and in those receiving amylomaize starch than in the ones fed normal starch. The transformation of cholesterol into coprostanol was much lower in CVE than in CVN rats. The part of coprostanol, expressed as a percentage of cholesterol + coprostanol, was $61.3 \pm 1.9 \%$ in CVN rats and $15.1 \pm 1.7 \%$ in CVE rats.

Intestinal pools and fecal excretion of bile acids. Total cholesterol and bile acid elimination (tables 3,4 ). - The amounts of bile acids in the small intestine and those in the cecum + large intestine were higher in GFN than in CVN rats while, on the contrary, fecal excretion was slightly less in GFN than in CVN rats. Under the effect of amylomaize starch, the amounts of small intestine bile acids, as well as fecal excretion of bile acids, increased in the GFE and CVE groups. Variations were the opposite in the hind gut of germfrees and conventionals where total amounts of bile acids decreased in GFE compared to GFN and increased in CVE compared to CVN. Total elimination of cholesterol and bile acids increased slightly under the effect of amylomaize starch in both types of rat. In the absence of dietary cholesterol, this elimination is approximately equal to total cholesterol biosynthesis. Expressed in $\mu$ moles per $100 \mathrm{~g}$ of body weight, it was: GFN $=11.9 \pm 0.8, \mathrm{GFE}=13.5 \pm 0.3, \mathrm{CVN}=13.2 \pm 0.3$, CVE $=16.4 \pm 1.3$ and the analysis of variance was : microflora : $p<0.025$; starch : $p<0.010$; interaction : NS.

Composition of fecal bile acids. - Under the effect of amylomaize starch, the percentage of cholic acid in GF rats tended to decline, mainly in favor of $\beta$ muricholic acid. In CV rats, bacterial transformation of bile acids was much lower in those fed amylomaize starch. The percentage of primary bile acids (particularly cholic and $\beta$-muricholic acids) was higher in CVE than in CVN rats and

TABLE 4

Average composition of fecal bile acids (in \%)

\begin{tabular}{|c|c|c|c|c|}
\hline \multirow[b]{2}{*}{ Acids } & \multicolumn{4}{|c|}{ Groups of rats } \\
\hline & GFN & GFE & CVN & CVE \\
\hline Cholic ..... & $17.0 \pm 0.4$ & $11.0 \pm 0.5$ & $3.0 \pm 0.3$ & $15.7 \pm 1.0$ \\
\hline$\alpha$-Muricholic $\ldots \ldots \ldots$ & $3.6 \pm 0.02$ & $2.9 \pm 0.3$ & $4.3 \pm 1.5$ & $4.4 \pm 0.2$ \\
\hline$\omega$-Muricholic $\ldots \ldots \ldots$ & & & $12.5 \pm 6.1$ & $7.0 \pm 1.9$ \\
\hline$\beta$-Muricholic $\ldots \ldots \ldots$ & $44.0 \pm 0.5$ & $48.3 \pm 0.4$ & $8.7 \pm 1.9$ & $30.6 \pm 1.5$ \\
\hline Hyodeoxycholic ...... & & & $23.2 \pm 7.0$ & $1.8 \pm 0.5$ \\
\hline Chenodeoxycholic .... & $2.1 \pm 0.1$ & $2.3 \pm 0.2$ & $1.1 \pm 0.2$ & $1.6 \pm 0.1$ \\
\hline Deoxycholic .......... & & & $12.3 \pm 0.8$ & $1.3 \pm 0.1$ \\
\hline Ursodeoxycholic ...... & $1.7 \pm 0.02$ & $2.5 \pm 0.2$ & & \\
\hline Lithocholic ......... & & & $6.0 \pm 0.8$ & $3.8 \pm 0.1$ \\
\hline Keto ............. & & & $20.0 \pm 1.6$ & $17.6 \pm 1.6$ \\
\hline Undetermined $\ldots \ldots \ldots$ & 31.4 & 33.0 & 8.7 & 15.8 \\
\hline
\end{tabular}


the opposite was true of bacterial metabolites (particularly deoxycholic, hyodeoxycholic and $\omega$-muricholic acids).

\section{Discussion.}

The effects of amylomaize starch on the general characteristics of GF and $\mathrm{CV}$ rats raise many questions. The values of dry matter digestibility and microscopic examination of the feces show that this starch was only partially digested by rat enzymes but that the microflora of the cecum and large intestine made a very efficient contribution to its digestion. This good digestibility in our CV rats was unexpected because Sandstedt et al. (1962) observed very low digestibility $(39 \%)$ of an amylose-rich starch in conventional rats. It is generally known that rats ingesting starches of low digestibility have a lower growth rate (Fujita et al., 1982). This would explain the lower growth of GFE rats compared to GFN rats but obviously would not explain the growth of CVE animals compared to CVN ones since these rats digested their diet well. The relative diminution in CVE rat growth was probably due to lower food intake. This contrasts with the higher food intake in GFE rats which seemed to try to compensate for their inability to digest the amylomaize starch well.

The increased cecal weight of rats ingesting carbohydrates of low digestibility, such as potato starch, has been reported by various authors (Rayssiguier and Remésy, 1977 ; Demigné et al., 1980). The mechanism of this action is probably due to the disappearance or non-availability of bacteria reducing the cecum which then becomes voluminous as in germfree rats. Not all the intestinal bacteria have the ability to reduce the large cecum of GF rats (Loësche, 1969 ; Sacquet et al., 1973). Bacteria capable of using amylomaize starch advantageously proliferate in the cecum. The result is that bacterial equilibrium is disturbed, causing the elimination or decrease of a number of other bacteria by mechanisms which are still unknown. It is also possible that bacterial metabolites of amylomaize starch, such as volatile fatty acids, lower the $\mathrm{pH}$ so that many bacterial enzymes become inactive. Changes in the microflora also cause the decrease or disappearance of cholesterol reduction to coprostanol, of $\beta$-muricholic transformation into $\omega$-muricholic and hyodeoxycholic acids and of cholic acid into deoxycholic acid. On the other hand, other bacterial enzyme activities, such as the deconjugation of bile acids, are retained. This conservation could be explained by the fact that numerous bacteria have these hydrolases and that some of the hydrolases have optimal activity at acid pH (Aries and Hill, 1970 ; Lewis and Gorbäch, 1972). Many changes in bacterial enzyme activities under the effect of dietary carbohydrates have already been reported. For instance, Drasar and Hill (1974) underlined the relationship between intestinal $\mathrm{pH}$ and some bacterial transformations, and Kellogg (1971) emphasized the disappearance of coprostanol under the effect of lactose or the disappearance of some bacterial metabolites of bile acids under the effect of potato starch.

To this list, we could probably add variations in hepatic cholesterol, the concentration and total amount of which decrease in CVE rats compared to CVN 
rats, while the reverse trend is noted in GFE rats compared to the GFN group. The same is true of the amount of bile acids in the hind gut ; this amount varies in an opposite way in germfrees and conventionals. The diminution found in GFE animals could be a result of accelerated transit due to the mechanical effect of the undigested starch grains, an effect not found in CVE animals mainly because the expansion of the cecum slows down transit and also because bacteria digest the starch grains.

All the other characteristics of cholesterol and bile acid metabolisms vary under the effect of amylomaize starch in the same way in GF and CV rats. These variations are probably a result of the direct effect of this starch on the organism. The elevation of the total amount of bile acids in the small intestine and the decreased concentration of plasma cholesterol are the two most important variations of this type. The decrease in plasma cholesterol agrees with the observations of Carroll et al. (1978) on potato starch. It is not related to starch indigestibility because amylomaize starch, poorly utilized in GFE animals, was well utilized in the CVE group. This again agrees with Carroll et al. who noticed the hypocholesterolemic effect of potato starch which was poorly digested in rats and well digested in rabbits. On the contrary, we did not find the marked augmentation in the transformation of cholesterol into bile acids reported by Carroll et al. when measuring ${ }^{14} \mathrm{CO}_{2}$ excretion in rats receiving $\left(26-{ }^{14} \mathrm{C}\right)$-cholesterol. Fecal elimination of cholesterol and bile acids was only slightly increased in CVE and GFE rats ; thus, amylomaize starch did not decrease plasma cholesterol concentration by increasing their fecal excretion, as advanced for some dietary fibers (Eastwood and Hamilton, 1968 ; Kritchevsky and Story, 1974 ; Oakenfull and Fenwick, 1978 ; Vahouny et al., 1978). Other hypotheses have to be put forward to explain the direct effect of this starch on the bile acid content of the small intestine and the concentration of plasma cholesterol. For instance, these effects might be related to the incomplete or slow digestion of amylose-rich starch in the small intestine.

Reçu en décembre 1982. Accepté en mars 1983.

Résumé. Effet d'un amidon de mais riche en amylose sur le métabolisme du cholestérol et des acides biliaires chez le rat axénique et holoxénique.

Des rats axéniques et holoxéniques reçoivent un aliment semi-synthétique contenant soit un amidon de maïs normal, soit un amidon de maïs riche en amylose (amylomaïs). Les quatre groupes de rats ainsi formés sont comparés pour apprécier les effets de ces deux types d'amidon et déterminer si la flore microbienne du tractus digestif est impliquée dans ces effets.

La présence d'amidon riche en amylose dans l'aliment diminue la croissance pondérale des rats axéniques et holoxéniques, augmente la consommation d'aliment chez les premiers et la diminue chez les seconds. Elle diminue peu la digestibilité apparente de la ration chez les rats holoxéniques et au contraire, la diminue fortement chez les rats axéniques. Elle ne modifie pas le poids du caecum chez les axéniques et augmente plus de quatre fois celui des holoxéniques. 
Chez les deux types de rats, l'amidon riche en amylose diminue fortement la concentration du cholestérol dans le plasma et accroît considérablement la quantité totale d'acide biliaire de l'intestin grêle mais modifie peu l'élimination fécale de cholestérol et d'acide biliaire. Elle augmente la concentration du foie en cholestérol chez les axéniques et la diminue chez les holoxéniques, et au contraire diminue la quantité totale d'acide biliaire dans l'intestin terminal chez les premiers et l'augmente chez les seconds. Elle ne modifie pas la déconjugaison des acides biliaires chez les rats holoxéniques mais diminue de manière importante les autres transformations bactériennes du cholestérol et des acides biliaires.

La flore microbienne du tractus digestif est certainement impliquée dans les effets exercés par cet amidon sur le poids du caecum, la digestibilité de la ration, la consommation alimentaire, la concentration du cholestérol dans le foie, la quantité d'acide biliaire dans l'intestin terminal, et évidemment les transformations du cholestérol et des acides biliaires. Elle n'intervient pas dans les autres effets exercés par cet amidon : en particulier, la forte diminution de la concentration du cholestérol dans le plasma.

\section{References}

ARIES V., HILL M. J., 1970. Degradation of steroids by intestinal bacteria. I. Deconjugation of bile salts. Biochim. biophys. Acta, 202, 526-534.

CARROLL K. K., HAMILTON R. M. G., HUFF M. W., FALCONER A. D., 1978. Dietary fiber and cholesterol metabolism in rabbits and rats. Am. J. clin. Nutr., 31, S 203-S 207.

CHEVALLIER F., LUTTON C., 1966. Vitesses des processus de renouvellement du cholesterol contenu dans son espace de transfert, chez le rat. 1. Méthodes et résultats obtenus dans le cas d'un régime semi-synthétique témoin. Bull. Soc. Chim. biol., 48, 507-524.

DEMIGNÉ C., RÉMÉSY C., RAYSSIGUIER Y., 1980. Effect of fermentable carbohydrates on volatile fatty acids, ammonia and mineral absorption in the rat caecum. Reprod. Nutr. Dévelop., 20, 1351-1359.

DRASAR B. S., HILL M. J., 1974. Bile acid degradation, 103-123. In DRASAR B. S., HILL M. J., Human intestinal flora. Acad. Press, London, New York, San Francisco.

EASTWOOD N. A., HAMILTON D., 1968. Studies on the adsorption of bile salts to non-absorbed components of diet. Biochim. biophys. Acta, 152, 165-173.

FUJITA S., GLOVER D. V., SUGIMOTO Y., FUWA H., 1982. Effects of partially digestible starchgranules on digestive enzymes of rats. Nutr. Rep. Int., 26, 175-181.

GRUNDY S. M., AHRENS E. H., MIETTINEN T. A., 1965. Quantitative isolation and gas-liquid chromatographic analysis of total fecal bile acids. J. Lipid. Res., 6, 397-410.

KELLOGG T. F., 1971. Microbiological aspects of enterohepatic neutral sterol and bile acid metabolism. Fed. Proc., 30, 1808-1814.

KRITCHEVSKY D., STORY J. A., 1974. Binding of bile salts in vitro by non-nutritive fiber. J. Nutr., 104, 458-462.

LEWIS R., GORBÄCH S., 1972. Modification of bile acids by intestinal bacteria. Arch. int. Med., 130, 545-549.

LOËSCHE W. J., 1969. Effect of bacterial contamination on cecal size and cecal contents of gnotobiotic rodents. J. Bact., 99, 520-526.

OAKENFULL D. G., FENWICK, D. E., 1978. Absorption of bile salts from aqueous solution by plant fibre and cholestyramine. Brit. J. Nutr., 140, 299-309.

RAYSSIGUIER Y., RÉMÉSY C., 1977. Magnesium absorption in the caecum of rats related to volatile fatty acids production. Ann. Rech. vét., 8, 105-110.

RIOTTOT M., SACQUET E., LEPRINCE C., 1980. Variations of bile salt pool size and secretion rate in rats according to the modes of sterilization and preparation of a semi-synthetic diet. Reprod. Nutr. Dévelop., 20, 1481-1488.

SACQUET E., LACHKAR M., MATHIS C., RAIBAUD P., 1973. Cecal reduction in " gnotoxenic " rats, 545-552. In J. B. HENEGHAN, Germfree research. Acad. Press, Inc., New York and London. 
SACQUET E., VAN HEIJENOORT Y., RIOTTOT M., LEPRINCE C., 1975. Action de la flore microbienne du tractus digestif sur le métabolisme des acides biliaires chez le rat. Biochim. biophys. Acta, 380, 52-65.

SACQUET E., MEJEAN C., RIOTTOT M., RAIBAUD P., 1977. Action du régime alimentaire et de la flore microbienne du tractus digestif sur le pool intestinal et l'excrétion fécale des acides biliaires chez le rat. Etude comparée chez des rats axéniques, gnotoxéniques et holoxéniques. Ann. Nutr. Alim., 30, 603-617.

SACOUET E., LEPRINCE C., RIOTTOT, M., 1979. Effect of different modifications of a semisynthetic diet on bile acid metabolism in axenic and holoxenic rats. Ann. Biol. anim. Bioch. Biophys., 19, 1677-1688.

SANDSTEDT R. M., STRAHAN D., UEDA S., ABBOT R. C., 1962. The digestibility of high-amylose corn starches compared to that of other starches. The apparent effect of the ae gene on susceptibility to amylase action. Cereal Chem., 37, 55-66.

SNEDECOR G. W., COCHRAN W. G., 1957. Méthodes statistiques. A.C.T.A. Paris, 6 éd.

TREXLER P. C., 1959. The use of plastics in the design of isolator systems in germfree vertebrates : present status. O. V. ST WITELOCK, F. N. FURNESS, P. A. STURGEON, éd. Ann. N. Y. Acad. Sci., 78, 29-36

VAHOUNY G. V., ROY R., GALLO L. L., STORY J. A., KRITCHEVSKY D., CASSIDY M., GRUND B. M., C. R. TREADWELL, 1978. Dietary fiber and lymphatic absorption of cholesterol in the rat. Am. J. clin. Nutr., 37, S 208-S 212. 